Article

\title{
Wood-Logging Process Management in Eastern Amazonia (Brazil)
}

\author{
Killian S. Lima ${ }^{1}$, Ana C. Meira Castro ${ }^{2, *(1)}$, J. Santos Baptista ${ }^{1}\left[\right.$ and Ulisses Silva ${ }^{3}(\mathbb{C}$ \\ 1 Associated Laboratory for Energy, Transports and Aeronautics (LAETA), Faculty of Engineering of \\ University of Porto (FEUP), Rua Dr. Roberto Frias, s/n, 4200-465 Porto, Portugal; \\ ayafuziel@hotmail.com (K.S.L.); jsbap@fe.up.pt (J.S.B.) \\ 2 CERENA and ISEP-School of Engineering, Polytechnic of Porto, Rua Dr. António Bernardino de Almeida, \\ 431, 4200-072 Porto, Portugal \\ 3 Department of Forestry, Federal University of Western Pará, Santarém, 68040-255 Pará, Brazil; \\ usc.silva@gmail.com \\ * Correspondence: amc@isep.ipp.pt
}

Received: 15 August 2020; Accepted: 9 September 2020; Published: 14 September 2020

check for updates

\begin{abstract}
In this work, the wood-logging process of four federal conservation units (FCUs) in the Eastern Amazonia forest are described and compared. The approach focused on on-site observation of activities and tasks performed during the process. As an outcome, it was observed that companies implement activities similarly, regardless of their specific know-how. The most significant difference was identified in the cross-cutting operation, which is carried out in several steps and which interferes with the efficiency of the activity and the exposure of workers to occupational risks. The use of geographic information systems (GIS) during planning and management activities, and the use of modern machinery equipped with safety devices, in combination with workers' theoretic and practical continuous training, were identified as crucial measures that assure operational efficiency in the four companies assessed. Seeking to contribute to the sustainable development of the Amazon forest, a generic model for wood logging is proposed, which brings together best practices identified in the companies studied and makes it possible to obtain the best benefit at the lowest workers' exposure to the risk of occupational accidents.
\end{abstract}

Keywords: Amazon forest; wood logging; forest sustainability; timber; risk; occupational accident

\section{Introduction}

The Brazilian Amazon forest, spanning roughly 4 million square kilometres, constitutes the largest expanse of the world's tropical forests. Unquestionably, these native forests offer the world vital environmental services, such as maintenance of biodiversity, water cycling, and carbon stocks. It also offers Brazil a considerable trade potential as it is the primary source of valuable tropical hardwood [1]. However, sustainable forest management in the Amazon faces an enormous challenge considering the urgent need for a balance between economic growth linked to forestry, discontinuing practices that promote forest resource degradation and loss of biodiversity, and the significant occupational accidents that frequently occur inside the forest [2-6].

Forest management, as a defined process, emerged in the 19th century in Europe. Subsequently, the model was adapted for Asian tropical forests and American forests by the 1940s. In Brazil, the first schools of forestry engineering were founded in the 1960s. The forest management process may be defined as a set of forest planning and exploration practices performed by taking into account environmental conservation practices in a manner that simultaneously guarantees that a forest is capable of continuously supplying either products or services [7]. This concept is quite broad and, 
in the context of forest management for timber purposes specifically, it is considered that this process encompasses a set of techniques that provide a careful harvest, in which only part of the large trees is harvested so that the smaller ones are saved until the next harvest [6]. In the last half of the 1990s, the Food and Agriculture Organization of the United Nations (FAO) proposed a set of techniques for forest management, also known as the Exploration Techniques with Reduced Impact, aiming to reduce the impacts on forest vitality during wood logging [8]. This approach results from concerns for maintaining growing stock and securing tree regeneration, and for soil and water quality [9].

In Brazil, the implementation of these techniques has been reported since the late 1990s $[10,11]$. During this time, it has been evidenced that the adaptation of the best practices available to each specific company condition provides more significant economic benefits for forest management [12]. By the 2000s, the adoption of these techniques by Brazilian Amazonia's timber companies started to be investigated scientifically, seeking to clarify and identify the main factors limiting the full implementation of these forest management practices [13]. In 2006, the law that specifically regulates the extraction of wood from forests and forest management practices was published. Subsequently, in 2009, technical management guidelines for mechanised timber production in upland forests from Brazilian's Amazonia were published [14]. Since then, this work has been considered standard operating procedure for this activity. However, much more research in this field is needed [15].

Since the early 1990s, the concept of corporate social responsibility (CSR) has increasingly been regarded as a way for forestry corporations to increase their profits while attending to customer and stakeholder demands, pressure from environmental and social pressure groups, and legal demands, public regulations, and procurement policies. One essential means to perform CSR in the forestry sector is certification, based on general standards, such as ISO 14001 Environmental Management Standards and ISO 45001 Occupational Health and Safety Management Standards, or based on forest certification schemes, such as the Forest Stewardship Council (FCS) and the Programme for the Endorsement of Forest Certification (PEFC). These approaches impose strict restrictions on corporations' activities because they demand substantial stakeholder consultation, such as with environmental nongovernmental organisations (ENGOs), industry associations, and social organisations. Nowadays, corporations also include occupational safety and health management in the company's overall management [16]. However, despite the ecological and socioeconomic importance of these management strategies, they cover only niche markets to date, and hence are considered neither viable nor realistic income alternatives for an entire region such as the Amazon [17-20].

A key issue in tropical forest management is wood logging. In general, this process comprises a sequence of three stages—prelogging, logging, and postlogging—grouped into activities and tasks. In wood logging, the harvesting operations include assessment, planning, road construction, and wood harvesting (felling, extraction, and transport).

The present study aims to describe and compare wood-logging processes used in forest management by four companies in Eastern Amazonia, where sustainable management of native forest is supposedly carried out in line with the Normative Instruction $\mathrm{N}^{\mathrm{o}} 5$ of the Brazilian Environment Ministry [21]. It is intended to verify whether there are differences in the execution of the activities in the four companies and to identify the critical issues and challenges in wood logging in the Brazilian Amazon. A generic model is then proposed, bringing together the observed best practices and the sequence of procedures to be followed. The proposed model will assist similar wood-logging companies and organisations in planning and inspection operations and, consequently, in obtaining more significant profits by reducing the risk of exposure to occupational accidents.

\section{Material and Methods}

\subsection{Study Area}

The Amazon region comprises 61\% of Brazil's land area and represents the largest continuous tropical forest in the world, hosting around $20 \%$ of the world's plant and animal species [1]. 
The investigation was carried out in four Federal Conservation Units (FCUs) located in Eastern Amazonia (Figure 1).

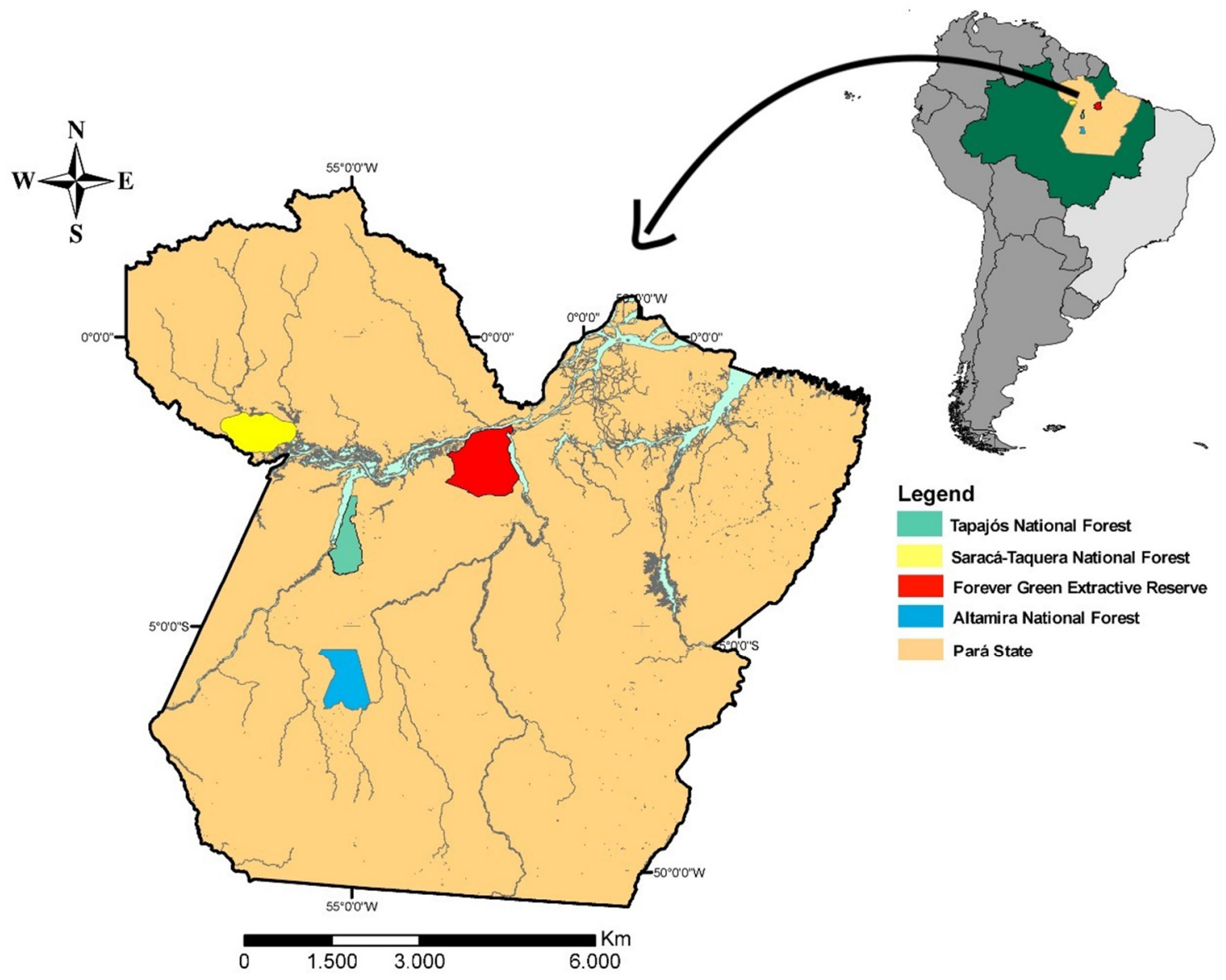

Figure 1. The location of the four Federal Conservation Units.

\section{(a) Tapajós National Forest (Flona Tapajós)}

The Brazilian government established the Tapajós National Forest in February 1974 [22]. This forest is located in the west of Pará state and covers an area of 530,620.65 ha in the municipalities of Aveiro, Belterra, Placas, and Rurópolis [23]. Access to the extraction zone is via federal road BR-163 in Belterra municipality. This area is under free concession to a cooperative (referred to as Institution A) composed of several associations of people who traditionally extract wood from forests, managed by the Chico Mendes Institute for Biodiversity Conservation (ICMBIO).

\section{(b) Saracá-Taquera National Forest (Flona Saracá-Taquera)}

The Saracá-Taquera National Forest was created in December 1989. It is located in the northwest of Pará state, close to the Rio Trombetas Biological Reserve [24]. Currently, it comprises an area of 441,152 ha in the municipalities of Terra Santa, Oriximiná, and Faro, near the border with the Amazonas state. The main access to this area is either across the town of Porto Trombetas, in the municipality of Oriximiná-on the left bank of the Trombetas River-or by the municipalities of Faro and Terra Santa, alongside the River Nhamundá. The area is under concession to three private institutions (referred to collectively as Institution B), and it is managed by the Brazilian Forest Service (BFS).

\section{(c) Verde para Sempre Extractive Reserve (Resex Verde para Sempre)}

The Verde para Sempre Extractative Reserve was created by the Brazilian government in November 2004 [25]. It is located in the west of Pará, bordering Amapá state. It currently holds an area of 
$1,289,362.78$ ha in the municipality of Porto de Moz. The main access to this area is either through the Amazon River or Xingu River. This area is under free concession to six associations and one cooperative (referred to as Institution C), composed of people traditionally involved in the extractive activity. The ICMBIO also manages it.

\section{(d) Floresta Nacional de Altamira (Flona Altamira)}

The Brazilian government created the Altamira National Forest in February 1998 [26]. It is located in the southwest of Pará state and comprises an area of 689,012 ha in the municipalities of Altamira, Itaituba, and Trairão. Access to this area is via BR-163 at Moraes de Almeida, a district of Itaituba municipality. The area is under the concession of two private companies (referred to as Institution D), and it is managed by the Brazilian Forest Service (BFS).

\subsection{Data Collection}

The data were collected for the four institutions (A-D) that operate in the FCUs previously mentioned. This number is considered an acceptable minimum for the type of study to be carried out [27]. The following sources of evidence were then used: (i) interviews with both general managers and operational teams, (ii) analysis of documents concerning operational and occupational health and safety procedures, and (iii) in loco observations of wood-logging activities.

For the interviews, open-ended questions were asked regarding both the forest management process and the logging activity, according to Vergara [28] and Cervo, Bervian, and Silva [29].

The Annual Operational Plans (AOP), which provide information on each institution's forest management, were obtained from their websites.

The observation of wood-logging activity was carried out in loco according to the classification of Lakatos and Marconi [30], being systematically arranged and previously planned. The fieldwork was recorded using written notes, photographs, and audio-visual records.

\subsection{Data Analysis}

Once information collection was completed, the wood-logging process was then described through workflows for each of the four areas. This approach allows performing a precise identification regarding not only the location particularities inherent to each institution but also the order in which the activities are performed and their specificities. The technological level of each institution was assessed qualitatively by evaluating its level of mechanisation and age of the equipment. The quality of electronic devices applied as auxiliary technology during the process was also considered. The use of personal protective equipment for occupational accident prevention was also assessed qualitatively.

\section{Results}

\subsection{General Organisation and Team Sizes}

All institutions were aware that the sustainability of the Brazilian Amazon forests results from the complex interaction of many direct and indirect environmental and social drivers. They promote sustainable forest management practices as they know this will help to increase their competitiveness.

The logging process has several steps performed according to the general organisation workflow shown in Figure 2.

Although, in general, the same practices are followed, the four institutions adopt their own organisation concerning the leadership hierarchy and activities developed. Regarding wood-logging activity, procedural sequence and corresponding tasks, as well as the number of teams involved and their sizes, are shown in Figure 3 and Tables 1-4.

The structure of the leadership hierarchy is different in the four institutions studied, varying mainly according to the size of the Annual Production Unit (APU) area. In 2019, Institution D established an APU area of 6414 ha, Institution B of 1000 ha, Institution A of 612 ha, and Institution C of less than 
200 ha. Different leadership scenarios were observed as well. A single worker managed all operations at Institution C, whereas no specific manager was assigned at Institution B. At both Institutions A and $\mathrm{D}$, there were managers for certain operations only. In the absence of a manager to coordinate and supervise operations, the institutions presented team leaders subordinated to either a technician or a forest engineer in charge of such activity.

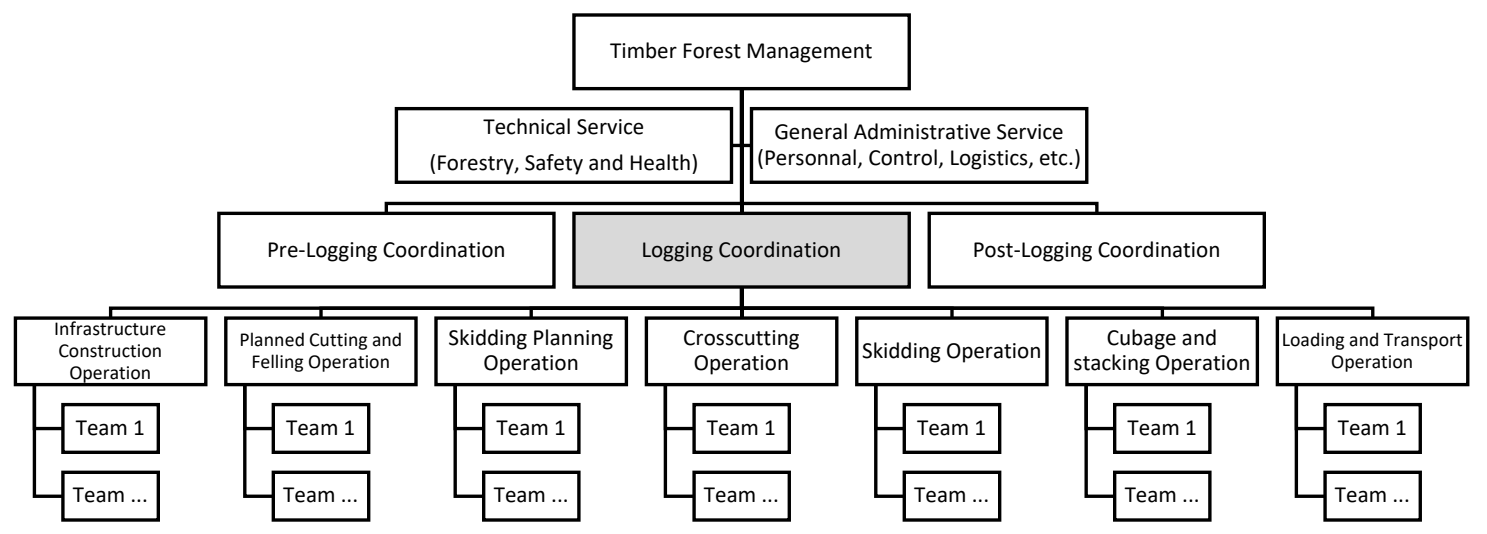

Figure 2. Standard general workflow of forest management observed in the four Federal Conservation Units.
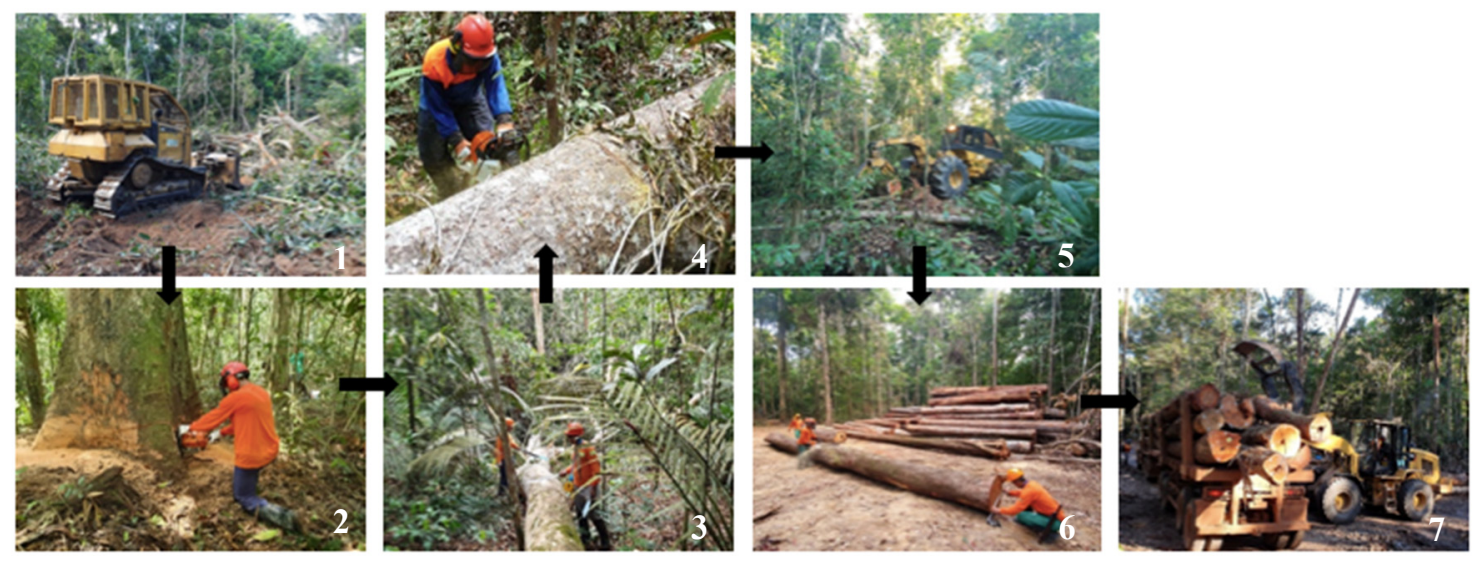

Figure 3. A general overview of the workflow in the wood-logging process. (1) Infrastructure construction; (2) planned cutting and felling; (3) skidding planning; (4) crosscutting top trees, bases, logs, and obstacles; (5) skidding; (6) cubage and stacking; (7) loading and transport.

The number and size of the teams were also divergent among institutions and varied according to task specificity, the time needed to execute the task, the size of the area to be explored, and the operational requirements imposed by terrain conditions. In summary, the number of teams operating simultaneously was identified: infrastructure construction (one to two teams); planned cutting and felling (twelve teams); skidding planning (one to six teams); cross-cutting (one to eight teams); skidding (one to four teams); cubage and stacking (one to two teams); loading and transportation (one to two teams).

\subsection{Activities in the Wood-Logging Process}

According to the workflows presented (Tables 1-4), the sequence of wood-logging activities and their correspondent procedures are remarkably similar. However, some differences were found and are described below. 
Table 1. Workflow, activities description, and the number of workers per team (Institution A).

\begin{tabular}{|c|c|c|}
\hline Institution A Workflow & Description of Activities & No. of Workers \\
\hline \multirow[t]{2}{*}{$\begin{array}{c}\text { (1) Infrastructure construction } \\
\text { (Pathways and Log Storage Yard) }\end{array}$} & $\begin{array}{l}\text { (1) Infrastructure construction consists in removing the vegetation * } \\
\text { with a crawler tractor, allowing machines and vehicles to move } \\
\text { through the pathways towards the log storage yards. The obstacles } \\
\text { are traced with a chainsaw while the trees that hinder the tractor } \\
\text { traffic are ripped out. To avoid accidents with tires drilling in } \\
\text { machines and vehicles, the cutting and cleaning of exposed roots are } \\
\text { also included in this activity. }\end{array}$ & $\begin{array}{l}01 \text { Crawler tractor operator }{ }^{* *} \text {; } \\
01 \text { Chainsaw operator; } \\
01 \text { Assistant; } \\
01 \text { Forestry technician. }\end{array}$ \\
\hline & $\begin{array}{l}\text { (2) Consists of performing the planned cutting and felling, according } \\
\text { to technical guidelines, before crosscutting the top trees ***. }\end{array}$ & $\begin{array}{l}01 \text { Chainsaw operator (Feller); } \\
01 \text { Helper. }\end{array}$ \\
\hline $\begin{array}{l}\text { (3) Skidding planning/Obstacle } \\
\text { crosscutting }\end{array}$ & $\begin{array}{l}\text { (3) Consists in laying out the area where the forestry tractor will drag } \\
\text { the logs. Then all obstacles along the route that may hinder traffic } \\
\text { are traced. }\end{array}$ & $\begin{array}{l}01 \text { Planner } \\
01 \text { Assistant (Planning); } \\
02 \text { Chainsaw operators (crosscutting). }\end{array}$ \\
\hline $\begin{array}{l}\text { (4) Crosscutting remaining } \\
\text { canopies, bases and logs/Skidding }\end{array}$ & $\begin{array}{l}\text { (4) Consists in crosscutting the remaining canopies and logs with a } \\
\text { machete or hollow and slicing them to facilitate dragging. Then the } \\
\text { logs are dragged with a tractor, which can also be performed by a } \\
\text { steel cable with a hook or articulated grapple. At the same time, there } \\
\text { is a chainsaw available to trace obstacles, if, by chance, they appear. }\end{array}$ & $\begin{array}{l}02 \text { Chainsaw operators (crosscutting); } \\
01 \text { Forestry tractor operator; } \\
02 \text { Assistants on the cable (Skidding) }\end{array}$ \\
\hline (5) Cubage and stacking & $\begin{array}{l}\text { (5) Consists of measuring logs and confirming the species in } \\
\text { accordance with the chain of custody presented on the harvest map, } \\
\text { besides tracking and documenting each step on the packing list. } \\
\text { Moreover, the process of sectioning with a sledgehammer and } \\
\text { crosscutting the log according to commercial length is also carried } \\
\text { out. Then the towers are stacked with a front loader. }\end{array}$ & $\begin{array}{l}01 \text { Annotator; } \\
02 \text { Chainsaw operators; } \\
\text { 02 Measurers; } \\
\text { 01 Sledgehammer user; } \\
01 \text { Loader operator. }\end{array}$ \\
\hline (6) Loading and transport & $\begin{array}{l}\text { (6) Consists of loading logs onto trucks, aiming to transport them } \\
\text { from the secondary log storage yards to the central yard, where they } \\
\text { are unloading and sorted by species. Subsequently, the logs are } \\
\text { transported from the central courtyard to industry, according to } \\
\text { requirements prescribed by law. }\end{array}$ & $\begin{array}{l}01 \text { Truck driver } \\
01 \text { Loader operator (secondary yard); } \\
01 \text { Data annotator; } \\
01 \text { Truck driver; } \\
\text { 01 Loader operator (central courtyard). }\end{array}$ \\
\hline
\end{tabular}

* According to the prelogging set-up planning, and in line with the requirements established by legal provisions, such as dimensions. Signals are made with assorted colours of plastic tapes for either the main or secondary pathways, being supported by physical maps and GPS.** There may be one motor grader operator when the improvement of the pathway infrastructure is necessary, ${ }^{* * *}$ except for the Jarana and Maçaranduba species, since it is believed that by maintaining the canopy for more time the frequency of cracks in the wood is reduced. ${ }^{* * * *}$ Unlike the tractor with cable dragging, the articulated grapple does not need a helper. 
The construction of infrastructure activity consists of opening pathways to allow either equipment circulation or building log yard storage. Chainsaws are used to cut obstacles, while crawler tractors remove the vegetation around the field. Exposed roots are cut and cleaned to avoid accidents with tires drilling in machines and vehicles. Despite the structure of facilities being similar in all institutions, it was observed that both Institutions B and D used better technological resources to carry out this activity, such as tablets with maps, GPS, and altimetric maps. Regarding the team size, three people were involved at Institution B, while there were four at Institution A (an additional forestry technician). Institutions $C$ and $D$ had five people (a planner and a helper).

The planned cutting and felling activities consist of undercutting the trees and directing the trunk to fall on the ground. These operations are carried out similarly in the four institutions, following the same technical guidelines regarding both safety procedures and cutting and felling techniques. A difference, however, was found in both Institutions A and D, which included crosscutting the treetops during this activity. Meanwhile, Institutions B and C do not perform treetop cuttings because it is considered that workers will be safer by avoiding accidents with branches during the felling operation. Regarding team size, the number of workers on each team was the same for all institutions, except Institution C, which used two helpers instead of one.

The skidding planning activity consists in laying out the pathway where the tractor will drag the logs. This activity is usually complemented by crosscutting obstacles on the pathway that may hinder machine movement. Institutions A, C, and D include both operations in the same activity, named skidding planning and obstacles crosscutting. Regarding team size, the number of workers on each work team is the same in both Institutions $C$ and D. Institution A has two chainsaw operators, which is twice the number observed in other institutions. Institution $B$, in contrast, does not use chainsaw operators in this activity, since the obstacle crosscutting operation is not considered. Instead, one planner and one helper for the skidding planning activity are used, similar to the other institutions.

The cubage consists of cutting the treetops and sectioning the trunks to improve the skidding activity. Moreover, it comprises cutting the log bases that have hollows visible high roots (catana). Typically, the trunk is cut with a chainsaw. This task is performed by a specialised worker with vast knowledge of the potential use of the wood in industry, thus avoiding waste and the loss of felled trees. Generally, the crosscutting activity occurs simultaneously with skidding activity at the storage yard, where the wood is stacked. However, it is not a frequent practice for all four institutions. Institution A, for instance, does not perform all the crosscutting activity in a concentrated way, and this activity is divided into three other steps: planned cutting and felling, skidding planning, and skidding. Then only part of the treetops is traced immediately after the felling activity.

Institution D performs crosscutting for all the treetops, while Institution B concentrates on a single activity of crosscutting treetops, logs, and obstacles and, sometimes, the bases as well. Finally, Institution $C$ considers the cross-cutting process included in two other activities-cutting and skidding planning. Concerning team sizes, all the institutions have a chainsaw operator (feller) and assistant on the team. However, at Institution A, since the crosscutting activity is not specifically considered, the team also has another chainsaw operator, a forestry tractor operator, and a dragline assistant.

The skidding activity consists of moving the logs from the felling place to the storage yards. Heavy equipment is used in this activity, which makes it one of the costliest steps in forest management processes in all institutions. In Institution A, this operation occurs simultaneously with the crosscutting activity. In the other institutions, this activity is carried out individually. If an operation of obstacle removal is required, the chainsaw operator from the packing list activity is called to support the process. The teams have one operator of forestry tractor equipped with an articulated grapple (Figure 3), or two helpers instead of one, in case of a tractor with a steel cable and hook. 
Table 2. Workflow, activities description, and the number of workers per team (Institution B).

\begin{tabular}{|c|c|c|}
\hline Institution B Workflow & Description of Activities & No. of Workers \\
\hline $\begin{array}{l}\text { (1) Infrastructure construction } \\
\text { (Pathways and Log Storage Yard) }\end{array}$ & $\begin{array}{l}\text { (1) Consists in following the vegetation removal guidelines, with } \\
\text { the assistance of a tablet and GPS, so that the tractor can remove } \\
\text { the obstacles, allowing the traffic of machines and vehicles along } \\
\text { the roads towards the log storage yard. The obstacles are traced } \\
\text { with a chainsaw. In the end, the helper cuts the exposed roots to } \\
\text { avoid accidents with the machines and vehicle tires. }\end{array}$ & $\begin{array}{l}01 \text { Crawler tractor operator; } \\
01 \text { Chainsaw operator; } \\
01 \text { Assistant. }\end{array}$ \\
\hline (2) Planned cutting and felling & $\begin{array}{l}\text { (2) Consists of cutting and felling, according to technical } \\
\text { guidelines. }\end{array}$ & $\begin{array}{l}01 \text { Chainsaw operator (Feller); } \\
01 \text { Helper. }\end{array}$ \\
\hline (3) Skidding planning & $\begin{array}{l}\text { (3) Consists of arranging, in a detailed way, the roads where the } \\
\text { logs will be dragged. Additionally, markings and notes are made } \\
\text { on the map. }\end{array}$ & 01 Planner with 01 Assistant. \\
\hline $\begin{array}{l}\text { (4) Crosscutting top trees, bases, logs and } \\
\text { obstacles }\end{array}$ & $\begin{array}{l}\text { (4) Consists of carrying out, singly, all the canopies cross-cutting } \\
\text { operations. At this step, the logs with machete or hollow, the } \\
\text { towers and the obstacles are traced to facilitate dragging through } \\
\text { the pathway. }\end{array}$ & $\begin{array}{l}01 \text { Chainsaw operator; } \\
01 \text { Helper. }\end{array}$ \\
\hline & $\begin{array}{l}\text { (5) Consists in dragging the logs with a forestry tractor, which is } \\
\text { carried out exclusively with an articulated grapple. A chainsaw } \\
\text { is rarely needed to trace any obstacle on the route at this step. }\end{array}$ & 01 Forestry tractor operator. \\
\hline (6) Cubage and stacking & $\begin{array}{l}\text { (6) Consists in measuring the logs and confirming the species in } \\
\text { accordance with the chain of custody presented on the harvest } \\
\text { map, as well as documenting each step on both packing list and } \\
\text { section with mark canvas. Additionally, the log is traced } \\
\text { according to commercial compliance. Then, the towers are } \\
\text { stacked with a loader. }\end{array}$ & $\begin{array}{l}\text { 01 Data annotator; } \\
01 \text { Chainsaw operator; } \\
01 \text { Measurer; } \\
01 \text { Painter; } \\
\text { 01 Poster warning worker; } \\
\text { 01 Loader operator. }\end{array}$ \\
\hline (7) Loading and transport & $\begin{array}{l}\text { (7) Consists of loading the logs onto trucks, aiming to transport } \\
\text { them from secondary log storage yards to the central yard, where } \\
\text { they are unloaded and sorted by species. Due to the proximity of } \\
\text { the industry, the loading from the central yard to the industry } \\
\text { does not always occur, so that the transportation can be } \\
\text { performed from the secondary yard to the industry, directly. }\end{array}$ & $\begin{array}{l}01 \text { Truck driver; } \\
01 \text { Loader operator; } \\
01 \text { Annotator. }\end{array}$ \\
\hline
\end{tabular}


Table 3. Workflow, activities description, and the number of workers per team (Institution C).

\begin{tabular}{|c|c|c|}
\hline Institution C Workflow & Description of Activities & No. of Workers \\
\hline $\begin{array}{l}\text { (1) Infrastructure construction } \\
\text { (pathways and log storage yard) }\end{array}$ & $\begin{array}{l}\text { (1) Consists in following the vegetation removal planning guidelines, } \\
\text { with the assistance of a manual map, so that the tractor can remove the } \\
\text { obstacles, allowing the traffic of machines and vehicles along the roads } \\
\text { towards the log storage yard. The obstacles are traced with a chainsaw. } \\
\text { In the end, the helper cuts the exposed roots to avoid accidents with } \\
\text { the machines and vehicle tires. }\end{array}$ & $\begin{array}{l}01 \text { Planner; } \\
01 \text { Assistant; } \\
01 \text { Chainsaw operator; } \\
\text { 01 Crawler tractor operator; } \\
01 \text { Assistant * }\end{array}$ \\
\hline (2) Planned cutting and felling & (2) Consists of cutting and felling, according to technical guidelines. & $\begin{array}{l}01 \text { Chainsaw operator (Feller); } \\
02 \text { Helpers. }\end{array}$ \\
\hline $\begin{array}{l}\text { (3) Skidding planning / Obstacle } \\
\text { crosscutting }\end{array}$ & $\begin{array}{l}\text { (3) Consists in setting up the path where the tractor will drag the logs, } \\
\text { and then all obstacles to tractor movement along the route are traced. }\end{array}$ & $\begin{array}{l}01 \text { Planner; } \\
01 \text { Assistant; and } \\
01 \text { Chainsaw operator. }\end{array}$ \\
\hline (4) Crosscutting toptrees, bases and logs & $\begin{array}{l}\text { (4) Consists in carrying out a crosscutting operation on the crowns and } \\
\text { logs bases with a machete or hollow and sectioning the logs, making } \\
\text { the drag easier }{ }^{* *} \text {. }\end{array}$ & $\begin{array}{l}01 \text { Chainsaw operator; } \\
02 \text { Helper. }\end{array}$ \\
\hline \multirow{2}{*}{ (5) Skidding } & $\begin{array}{l}\text { (5) Consists in dragging the logs with either forestry tractor or steel } \\
\text { cable with hook/hydraulic claw } * * * \text { The chainsaw from the storage } \\
\text { yard helps to trace obstacles along the route. }\end{array}$ & $\begin{array}{l}01 \text { Forestry tractor operator; } \\
02 \text { Cable helper; and } \\
01 \text { Claw helper. }\end{array}$ \\
\hline & $\begin{array}{l}\text { (6) Consists of measuring the logs and confirming the species in } \\
\text { accordance with the chain of custody presented on the harvest map. } \\
\text { Additionally, each step is documented on both the packing list and } \\
\text { section with an aluminium plate inscription. Additionally, the log is } \\
\text { traced according to commercial compliance. Then the towers are } \\
\text { stacked with a loader. }\end{array}$ & $\begin{array}{l}01 \text { Annotator; } \\
02 \text { Chainsaw operators; } \\
\text { 02 Measurers; } \\
\text { 01 Poster worker; } \\
01 \text { Loader operator. }\end{array}$ \\
\hline (7) Loading and transport & $\begin{array}{l}\text { (7) Consists of loading logs onto trucks, aiming to transport them from } \\
\text { secondary log storage yards to the central yard, where they are } \\
\text { unloaded and sorted by species. Subsequently, the logs in the central } \\
\text { yard are loaded onto ferries, using only the front loader, which takes } \\
\text { the cargo to the industry by water, as recommended by law. }\end{array}$ & $\begin{array}{l}01 \text { Truck driver and } \\
01 \text { Loader operator; } \\
01 \text { Data annotator; } \\
\text { 01 Loader operator. }\end{array}$ \\
\hline
\end{tabular}

* There may be one motor grader operator when the improvement of the pathway infrastructure is necessary. ${ }^{* *}$ Two assistants participate in this activity, as they measure the log to predict the volume according to regulation by AUTEX (Exploration Authorization). ${ }^{* * *}$ There are two ways to perform the dragging activity: by a forestry tractor coupled with a cable device and managed by two helpers, or by hydraulic grab, which uses only one helper. 
Table 4. Workflow, activities description, and the number of workers per team (Institution D).

\begin{tabular}{|c|c|c|}
\hline Institution D Workflow & Description of Activities & No. of Workers \\
\hline $\begin{array}{l}\text { (1) Infrastructure construction } \\
\text { (Pathways and Log Storage Yard }\end{array}$ & $\begin{array}{l}\text { (1) Consists in following the vegetation removal planning guidelines, with } \\
\text { the assistance of GPS and an altimeter map, considering the level curves } \\
\text { and location of rocks for the vegetation removal with a crawler tractor, } \\
\text { allowing the traffic of machines and vehicles along the roads toward the } \\
\text { log storage yard. Obstacles are traced with a chainsaw when necessary. }\end{array}$ & $\begin{array}{l}01 \text { Planner; } \\
02 \text { Assistant; } \\
01 \text { Chainsaw operator; } \\
01 \text { Crawler tractor operator * }\end{array}$ \\
\hline $\begin{array}{l}\text { (2) Planned and cutting and felling / } \\
\text { crosscutting top trees }\end{array}$ & $\begin{array}{l}\text { (2) Consists of performing the cutting and felling planned, according to } \\
\text { technical guidelines, before crosscutting the top trees }{ }^{* *} \text {. }\end{array}$ & $\begin{array}{l}01 \text { Chainsaw operator; } \\
01 \text { Helper. }\end{array}$ \\
\hline $\begin{array}{l}\text { (3) Skidding planning / Obstacle } \\
\text { crosscutting }\end{array}$ & $\begin{array}{l}\text { (3) Consists in laying out the area where the tractor will drag the logs. } \\
\text { Then, all obstacles along the route that may hinder traffic are traced. }\end{array}$ & $\begin{array}{l}01 \text { Planner with } 01 \text { Assistant; } \\
01 \text { Chainsaw operator. }\end{array}$ \\
\hline (4) Crosscutting bases and logs when & $\begin{array}{l}\text { (4) Consists in crosscutting the remaining canopies and logs with a } \\
\text { machete or hollow and slicing them to facilitate the harrow. }\end{array}$ & $\begin{array}{l}01 \text { Chainsaw operator (Feller); } \\
01 \text { Helper }\end{array}$ \\
\hline & $\begin{array}{l}\text { (5) Consists of dragging logs with a tractor coupled to a steel cable with } \\
\text { pyrite. The chainsaw from the storage yard helps to trace obstacles along } \\
\text { the route when necessary. }\end{array}$ & $\begin{array}{l}01 \text { Forestry tractor operator; } \\
\text { and } 01 \text { Helper. }\end{array}$ \\
\hline (6) Cubage and stacking & $\begin{array}{l}\text { (6) Consists in measuring the logs and confirming the species in } \\
\text { accordance with the chain of custody presented on the harvest map and } \\
\text { recording on a tablet using the packing list software section with bar code } \\
\text { printing. Additionally, the log is traced according to commercial } \\
\text { compliance. Then the towers are stacked with a loader. }\end{array}$ & $\begin{array}{l}01 \text { Data annotator; } \\
02 \text { Chainsaw operator; } \\
02 \text { Measurer; } \\
01 \text { Poster warning worker; } \\
01 \text { Loader operator. }\end{array}$ \\
\hline (7) Loading and transport & $\begin{array}{l}\text { (7) Consists of loading logs onto trucks, aiming to transport them from } \\
\text { secondary log storage yards to the central yard, where they are unloaded } \\
\text { and sorted by species. Subsequently, the logs in the central yard are } \\
\text { loaded for industry, according to requirements prescribed by law }\end{array}$ & $\begin{array}{l}01 \text { Truck driver; } \\
01 \text { Loader operator; } \\
01 \text { Controller; } \\
01 \text { Truck driver and } \\
01 \text { Loader operator. }\end{array}$ \\
\hline
\end{tabular}

* There may be one motor grader operator when the improvement of the pathway infrastructure is necessary. ** There is a greater complexity in carrying out the activities, mainly due to the relief, rock formation, and caves. ${ }^{* * *}$ The differential is the use of a barcode reader device for issuing invoices. 
The cubage and stacking activity consists in measuring logs and confirming their species according to the chain of custody, which is presented on the harvest map. This activity is very relevant in the forest management process and comprises tracking and documenting each step on a packing list before logs are stacked with a front loader. It is after this activity that the institution starts the chain of custody registration, which assists in the control of wood-logging activity and, especially, assists the assessment of its productivity and costs. Teams at all the institutions have a wood recorder, two measurers, an identifier (that will use a plaque or a sledgehammer, depending on the labelling method used for wood identification), and a loader operator. Institutions A, C, and D have, additionally, two more workers on the team-a measurer and a chainsaw operator. Concerning the labelling method for wood identification, Institution A uses a sledgehammer to insert its typographic identification into the wood directly. Institution $C$ uses labels made of aluminium plates, while Institution D uses labels made of paper with a barcode (Figure 4). This barcode system of labelling the logs allows more natural control of the chain of custody, ensuring traceability integrity. Although it has a smaller team, Institution B, assigns a painter exclusively for the labelling function, to mark the dimensions of each trunk with a brush.

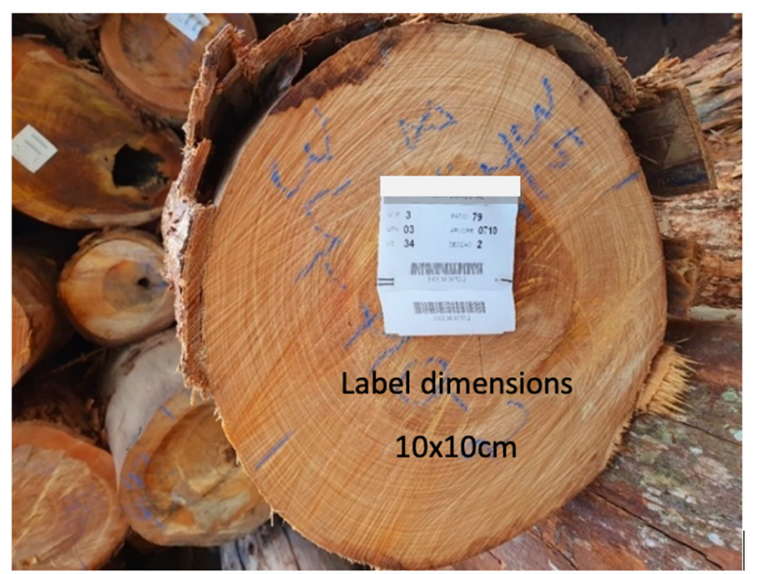

Figure 4. Wood identification with a barcode.

The wood-loading and transporting activity consists of loading logs onto trucks and transporting them from the secondary yards to the central yard, where they are unloaded. At the central yard, logs are sorted according to their species and, subsequently, transported to industrial units. All institutions perform this activity following requirements prescribed by law. The method of transferring the wood from the secondary yard to the central yard is similar in all institutions. However, Institution B, due to its geographical proximity, transports wood from the secondary storage yard directly to the industrial units. Institutions A, B, and D ship timber to the industrial units by truck, while Institution C uses a ferry across the river. In all institutions, the teams have a truck driver, a loader operator, and a note-taker. This number doubles whether there is an intermediate storage yard facility or not.

Currently, not all timber products are valuable, and only Institution B sells both smaller and larger logs. In all institutions, harvesting and timber transport were considered among the most economically impactful activities in the composition of the product final cost, owing to the costs related to mechanisation (machinery costs with acquisition and maintenance).

\subsection{The Technological Level of the Institutions}

In the wood-logging process, it is extremely useful to use management software and GIS, not only for the planning and management processes themselves but also for infrastructure construction and maintenance. Among the institutions studied, Institution D displayed the most advanced technology, using both specific software to control the number of trees extracted and GPS devices with GIS software. These assisted in road planning and construction, mapping of inventoried and selected trees for cutting, 
and skidding planning and execution. In other institutions, GPS was used only as a primary tool, essentially to collect geographic data for map development in the prelogging process.

In general, all the institutions followed Brazilian law and regulation, so they had sufficient and adequate machinery to operate their wood-logging activity. However, not all equipment is owned by the institutions; sometimes it is necessary to rent equipment. Institution B was the one with the best and most modern equipment.

\subsection{Environmental Certification and Work Conditions}

Three of the four institutions have certified their management procedures following the Forest Stewardship Council (FSC).

Concerning occupational health and safety issues, all institutions followed safety procedures in line with Brazilian standards [31]. Logging exposes workers to occupational accidents mainly due to the extreme climate conditions inside the Amazon forest-extremely high temperatures, humidity, and solar radiation - and the use of the equipment for wood cutting and mobilisation. Thus, all institutions provide technical support on occupational safety and health by qualified professionals who train workers on safety procedures. The institutions also provide safety equipment to their workers, such as leggings, boots, helmets, masks, gloves, and hearing protectors.

\section{Discussion}

Wood-logging in Eastern Amazonia is carried out using manual and semimechanised methods and with a large labour contingent, operating under conditions adverse to well-being, safety, and health. Positive and negative aspects were identified in all the institutions studied, as were opportunities to improve the process and mitigate threats.

The wood-logging management process was conducted similarly in all four institutions analysed. The main difference concerned the crosscutting operation, which is carried out at several steps, performed in a specific manner for each institution, and thus under specific management approaches. The challenge in optimising this activity has also been reported by several researchers $[14,32-35]$ in other forests in the Brazilian Amazon, but it is not exclusive to this area in Brazil. Several studies have even reported this issue in coniferous woods and hardwoods management in temperate forests [36,37].

Concerning human resources, workers in the Brazilian Amazon are typically recruited far away from the institutions' operational sites. This circumstance reduces the frequency of contact with family members and tends to demotivate workers and sometimes to promote absenteeism. At Institution $\mathrm{D}$, for instance, most workers have been recruited from approximately $500 \mathrm{~km}$ away. To counter this trend, Institutions A, B, and C make a considerable effort nowadays to recruit workers from the local town and the surroundings, which makes their transportation easier and minimises the periods of separation from their families.

Another important aspect related to human resources is the workers' education level. Currently, about $45 \%$ of the population of the Brazilian Amazon has income below the poverty line, and this directly impacts forestry workers' level of education, which is a considerably low degree of literacy [1]. A small group of illiterate workers was also observed at Institution C, which undoubtedly hinders the efficient execution of technical procedures. However, a positive is that workers from all four institutions, whose ages range between 20 years and 40 years, demonstrated considerable knowledge and experience in the logging tasks for which they were hired and were, as well, very willing to receive technical training and learn how to deal with new equipment and technologies. The average age of workers at Institutions B and D was less than at the other institutions, and this positively influenced their ability to use technologies and equipment adequately and efficiently.

In the wood-logging process, it is unquestionable that the inclusion of both modern machinery and informatic applications such as GIS in operations planning is essential. They are well known to make forest management as profitable as possible with minimal damage to the environment $[38,39]$. 
This directly impacts the institutions' need to provide their employees with adequate and effective technical training.

Regarding the quality of the information given to the workers, Institution B presented the best practices, because operational planning is presented to workers in detail, leading to a more significant optimisation of resources.

With the exposure of the workers to occupational risks, some weaknesses and threats were observed. The wood-logging process is, nowadays, internationally recognised as the most dangerous kind of occupational activity [40]. Furthermore, performing this activity in the Amazon exposes workers more significantly to the risk of occupational accidents than in any other forest, because total mechanisation of the process is not possible in this region of Brazil. However, it is well known that Brazil has one of the most advanced and extensive legislations on the protection of workers' health, especially concerning the work environment [31]. Regulations address the best forest management practices that integrate quality, environment, and occupational safety standards.

Additionally, it is also well known that if forest certification schemes are adopted, either to meet customer demands or to avoid being targeted by environmental group networks, corporations can mark their products with an eco-label, which allows customers to trace sustainable products along the supply chain [41,42]. Considering this, all four institutions tended to standardise activities not only to increase productivity and efficiency but also to reduce the risks of occupational accidents. Finally, it was observed that the institutions tried to reduce to the minimum the number of workers and machinery involved in the activities, aiming, with this approach, to reduce the exposure of workers to occupational risks.

\section{The Proposed Model}

The sustainability, profitability, and efficiency of the wood-logging process in the Brazilian Amazon forests result from the complex interaction of several direct and indirect drivers. It is unquestionable that certification is an essential tool for sustainable forest management, as it promotes compliance with environmental and social legislation, as well as contributes to the assurance that an active forest management plan is accomplished [43]. Certification is also fundamental for the inclusion of CSR in the forest industry. This represents an important means to respond to the emerging responsible procurement demands that companies are facing nowadays and a way to increase competitive advantage in the forestry market. In this context, the wood-logging model for Eastern Amazonia proposed in the present study aims to bring together the best practices identified in the four institutions studied, primarily those regarding both the sequences of activities and the level of information available following the current standard procedures, norms, and guides (Table 5).

This strategy was established to encourage the use of forests for wood production under environmental, economic, and social sustainability principles. It is also intended to reinforce the important role given by certification schemes, once it is globally recognised that they boost institutions' reputation in competitive global markets. The implementation of this model of sustainable practices and compliance with regulations may imply internal costs. However, this must not be perceived in a negative way but rather as an opportunity to reduce the illegal timber trade and occupational accidents. Some studies have reported that the wood-logging process starts with the logging activity, as it is considered that "infrastructure construction" activity belongs to the prelogging process [44]. However, the present model considers that this activity should be the first activity in a logging process (after the licensing process has been approved), similarly to the approach taken by the four institutions assessed. 
Table 5. A proposed model for wood-logging activity in timber forest management.

\begin{tabular}{|c|c|c|}
\hline Workflow & Description of Activities & No. of Workers \\
\hline $\begin{array}{l}\text { (1) Infrastructure construction } \\
\text { (pathways and log storage yard) }\end{array}$ & $\begin{array}{l}\text { (1) Consists in removing vegetation and obstacles with a crawler } \\
\text { tractor and a chainsaw, allowing machines and vehicles to move } \\
\text { through the forest, and construction of roads to allow the flow of } \\
\text { personnel, machines, and wood across the forest and yards. }\end{array}$ & $\begin{array}{l}01 \text { Planner; } \\
01 \text { Crawler Tractor Operator; } \\
01 \text { Chainsaw Operator; } \\
01 \text { Helper. }\end{array}$ \\
\hline (2) Planned cutting and felling & $\begin{array}{l}\text { (2) Consists of cutting and felling the previously selected trees, taking } \\
\text { into account the natural inclination of trees, the projection of their } \\
\text { branches in the canopy, and the spatial distribution of the } \\
\text { neighbouring trees. }\end{array}$ & $\begin{array}{l}01 \text { Chainsaw Operator; } \\
01 \text { Helper. }\end{array}$ \\
\hline (3) Skidding planning & $\begin{array}{l}\text { (3) Consists of carefully planning the path through which the logs will } \\
\text { be dragged by a forestry tractor and inserting orientation signs with } \\
\text { the aid of coloured ribbons. This path should also be inserted on the } \\
\text { planning map. }\end{array}$ & $\begin{array}{l}01 \text { Planner; } \\
01 \text { Helper. }\end{array}$ \\
\hline $\begin{array}{l}\text { (4) Crosscutting top trees, bases, } \\
\text { logs and obstacles }\end{array}$ & $\begin{array}{l}\text { (4) Consists of carrying out complementary cutting operations, such as } \\
\text { the separation of the canopy from the rest of the tree, the separation of } \\
\text { the base of the logs, and the shortening of very long logs to facilitate } \\
\text { the dragging and the cutting of roots or fallen trees that are obstacles in } \\
\text { the paths previously defined for dragging the wood. }\end{array}$ & $\begin{array}{l}01 \text { Chainsaw Operator; } \\
01 \text { Helper. }\end{array}$ \\
\hline (5) Skidding & $\begin{array}{l}\text { (5) Consists of dragging the logs along the planned paths, using a } \\
\text { forestry tractor, preferably equipped with an articulated grapple. }\end{array}$ & 01 Forestry Tractor Operator. \\
\hline (6) Cubage and stacking & $\begin{array}{l}\text { (6) Consists of measuring the diameters and lengths of segments of } \\
\text { felled tree logs and dragging them to the storage yard where the wood } \\
\text { volume will be estimated. Then, the logs will be accommodated in an } \\
\text { organised manner in the storage yards. }\end{array}$ & $\begin{array}{l}01 \text { Annotator; } \\
01 \text { Chainsaw Operator; } \\
02 \text { Measures; } \\
\text { 01 Sledgehammer user; } \\
01 \text { Loader operator. }\end{array}$ \\
\hline (7) Loading and transport & $\begin{array}{l}\text { (7) Consists of the packaging of the tree logs in trucks using a front } \\
\text { loader to transport the wood to the central yard and to the industry. }\end{array}$ & $\begin{array}{l}01 \text { Truck driver and } \\
01 \text { Loader operator; } \\
01 \text { Data annotator; }\end{array}$ \\
\hline
\end{tabular}


Given that the "skidding planning" activity depends on other activities, it must be carried out by professionals qualified in recognising the relief and the vegetation both around the area and the obstacles, as well as the constraints due to the machine's dimension and its mobility capacity. Moreover, it is important to provide workers with the possibility to use, during this activity, technological devices, such as GPS, and software to monitor and record forest management, such as GIS. That is a crucial application to identify and classify trees, define the number of trees to be felled, and implement warning signs on the working maps to indicate the presence of obstacles that can hinder the forestry tractor movement and, thus, avoid having to repeat an obstacle crosscutting operation in skidding activity, for instance. It is well known that interruptions in the skidding operation are mainly due to having to replan the layout to remove or avoid obstacles, which corresponds to about $55.6 \%$ of the total stoppages [38].

In this proposal, it is suggested that the crosscutting step should be considered a single activity in the wood-logging process. This strategy will allow optimising not only human resources and machinery involved but also minimise workers' exposure to occupational risks. Crosscutting the tree crown immediately after felling increases the workers' exposure to accidents because of the possible detachment of branches that are often stuck in the canopy. Likewise, performing crosscutting simultaneously with the skidding activity exposes workers to the accident hazard because either the chainsaw operator or helper can be easily reached by the vegetation that was broken by the machine.

Using a forestry tractor on steep and rocky terrain is commonly considered to be a significantly tricky operation. For this reason, the use of a forest tractor with articulated grapple is recommended for the skidding activity. These machines possess an independent hydraulic system for the grapple, which allows the skidding activity to be performed by the tractor operator only, without the need of helpers. In this way, the exposure of workers to the risk of occupational accidents is reduced and, besides, this type of machine allows logs of a full commercial length to be dragged, which can be reflected in an increase in the site's productivity.

In this proposal, it is recommended that all trees be barcode labelled. This option was observed at Institution D and is considered to be, undoubtedly, the best practice since it not only makes monitoring of the chain of custody easier but also accelerates the wood shipping process, facilitating the issuance of invoices and reducing human error committed during data control annotation. The use of a sledgehammer that was observed at Institution A as a way of recording log identification tends to be discontinued as it was reported to be the cause of severe ergonomic damage to workers.

Because wood-logging is an activity with a high risk of occupational accidents [45-47], the proposed model considers that the reduction in occupational accident risks can be achieved if the institutions ensure workers receive training to comply with safety rules, especially on the mandatory use of personal protective equipment for all tasks. At the same time, institutions should monitor compliance with safety rules.

\section{Conclusions}

The execution of the wood-logging activity was similar in each of the logging institutions studied. The main difference was identified at the crosscutting operation, which is performed several times during different activities. This reflects a decreased efficiency of wood-logging activity and an increase in unnecessary worker exposure to occupational risks. The "skidding planning" activity is a crucial step that, if performed carefully, will improve the efficiency of the process globally.

The use of advanced machinery equipped with safety devices and forestry tractors with articulated grapples in the tree skidding operation is fundamental to reduce workers' exposure to the risk of occupational accidents. The use of digital technology, remote sensing, and geoprocessing during the wood-logging process also revealed enormous benefits, which were mainly reflected in a better performance in information management, in an optimisation of time spent in activities, and in the reduction in costs. 
For efficient wood-logging, it is necessary to have teams well trained not only in technical and practical skills but also in occupational safety knowledge. In this context, it was observed that all four institutions studied offered training in health and safety to their teams, especially training for the cutting and felling operation, and provided safety equipment to workers. However, since the Eastern Amazonia is a warm and humid environment, it was observed that this equipment was not frequently used, making it difficult for safety engineers, who often had to doublecheck the use of this equipment by the employees.

This paper contributes to the present state of research on the execution of a sustainable forest management process, particularly the execution of the wood-logging process in Eastern Amazonia. Knowledge on the importance of including schemes for both sustainable forestry certification and occupational safety and health management was gathered, and a wood-logging model that integrates the best practices to be considered towards supplying a globally sustainable product is provided.

Author Contributions: Conceptualization, K.S.L., A.C.M.C. and J.S.B.; field work K.S.L.; data curation, K.S.L.; methodology K.S.L., A.C.M.C. and J.S.B.; formal analysis, K.S.L., A.C.M.C., J.S.B. and U.S.; supervision, A.C.M.C. and J.S.B.; validation, A.C.M.C., J.S.B. and U.S.; writing-original draft, K.S.L. and U.S.; writing-review and editing, A.C.M.C. and J.S.B. All authors have read and agreed to the published version of the manuscript.

Funding: This research was funded by CERENA's strategic project FCT-UIDB/04028/2020, by the Biomechanics and Health Unit of the Associated Laboratory for Energy, Transports and Aeronautics (LAETA/INEGI), and by the Doctoral Program in Occupational Safety and Health of the University of Porto.

Conflicts of Interest: The authors declare no conflict of interest.

\section{References}

1. FAO and UNEP. The State of the World's Forests 2020. Forests, Biodiversity and People; Food and Agriculture Organization: Rome, Italy, 2020. [CrossRef]

2. Poschen, P. Forestry, a safe and healthy profession? Unasylva 1993, 44, 1. Available online: http://www.fao. org/docrep/u8520e/u8520e00.htm (accessed on 20 July 2020).

3. Azevedo-Ramos, C. Sustainable development and challenging deforestation in the Brazilian Amazon: The good, the bad and the ugly. Unasylva 2008, 59, 12-16. Available online: http://www.fao.org/3/i0440e03.htm (accessed on 11 September 2020).

4. Araujo, M.; Kant, S.; Couto, L. Why Brazilian companies are certifying their forests? For. Policy Econ. 2009, 11, 579-585. [CrossRef]

5. Siry, J.P.; Cubbage, F.W.; Ahmed, M.R. Sustainable forest management: Global trends and opportunities. For. Policy Econ. 2005, 7, 551-561. [CrossRef]

6. Verissimo, A.; Barreto, P.; Mattos, M.; Tarifa, R.; Uhl, C. Logging impacts and prospects for sustainable forest management in an old Amazonian frontier: The case of Paragominas. For. Ecol. Manag. 1992, 55, 169-199. [CrossRef]

7. Espada, A.; Pires, I.; Lentini, M.; Bittencourt, P. Manejo Florestal e Exploração de Impacto Reduzido em Florestas Naturais de Produção da Amazônia. IFP-Instituto Floresta Tropical, 2015. Available online: http://ift.org.br/wp-content/uploads/2014/11/Informativo-T\%C3\%A9cnico-1.pfd (accessed on 20 July 2020).

8. Dykstra, P.; Heinrich, R. FAO Model Code of Forest Harvesting Practice; Food and Agriculture Organization: Rome, Italy, 1996; Available online: http://www.fao.org/3/v6530e/v6530e00.htm (accessed on 20 July 2020).

9. Putz, E.; Sist, P.; Fredericksen, T.; Dykstra, D. Reduced-impact logging: Challenges and opportunities. For. Ecol. Manag. 2008, 256, 1427-1433. [CrossRef]

10. Barreto, P.; Amaral, P.; Vidal, E.; Uhl, C. Costs and benefits of forest management for timber production in eastern Amazonia. For. Ecol. Manag. 1998, 108, 9-26. [CrossRef]

11. West, T.A.P.; Vidal, E.; Putz, F.E. Forest biomass recovery after conventional and reduced-impact logging in Amazonian Brazil. For. Ecol. Manag. 2014, 314, 59-63. [CrossRef]

12. Holmes, T.P.; Blate, G.; Zweede, J.; Pereira, R.; Barreto, P.; Boltz, F.; Bauch, R. Financial and ecological indicators of reduced impact logging performance in the eastern Amazon. For. Ecol. Manag. 2002, 163, 93-110. [CrossRef] 
13. Sabogal, C.; Lentini, M.; Pokorny, B.; Silva, J.; Zweede, J.; Veríssimo, A.; Boscolo, M. Manejo Florestal Empresarial na Amazônia Brasileira: Restrições e Oportunidades-Relatório Síntese. CIFOR—Center for International Foresty Research, 2006. Available online: http://www.ift.org.br/wp-content/uploads/2015/05/ Sabogal_etal_2006a.pdf (accessed on 20 July 2020).

14. Sabogal, C.; Porkorny, B.; Silva, M.; Carvalho, P.; Zweede, C.; Puerta, R. Diretrizes técnicas de manejo para produção madeireira mecanizada em florestas de terra firme na Amazônia brasileira. Embrapa Amazônia Oriental, 2009. Available online: https://www.embrapa.br/busca-de-publicacoes/-/publicacao/853000/ diretrizes-tecnicas-de-manejo-para-producao-madeireira-mecanizada-em-florestas-de-terra-firme-naamazonia-brasileira (accessed on 20 July 2020).

15. Nasi, R.; Frost, P. Sustainable forest management in the tropics: Is everything in order but the patient still dying? Ecol. Soc. 2009, 14, 40. Available online: http://www.ecologyandsociety.org/vol14/iss2/art40/ (accessed on 20 July 2020).

16. Johansson, J. Why do forest companies change their CSR strategies? Responses to market demands and public regulation through dual-certification. J. Environ. Plan. Manag. 2014, 5, 349-368. [CrossRef]

17. Schulze, M.; Grogan, J.; Vidal, E. Forest certification in Amazonia: Standards matter. Oryx 2008, 42, $229-239$. [CrossRef]

18. Pescador, C.; Lisboa, G.; Stepka, T.; Kurchaidt, S. Safety work in the forest harvest: The first results. Ambiência 2013, 9, 397-410. [CrossRef]

19. Reyer, C. Sustainable development of the Amazon forest: A fine line between conservation and exploitation? Sustain. Sci. Pract. Policy 2017, 5, 38-44. [CrossRef]

20. McDermott, C.; Irlandb, L.; Pacheco, P. Forest certification and legality initiatives in the Brazilian Amazon: Lessons for effective and equitable forest governance. For. Policy Econ. 2015, 50, 134-142. [CrossRef]

21. Legislação Brasileira. Normativa $N^{\circ}$ 5, de 11 de dezembro de 2006. Available online: http://www.lex.com. br/doc_1081404_INSTRUCAO_NORMATIVA_N_5_DE_11_DE_DEZEMBRO_DE_2006.aspx (accessed on 20 July 2020).

22. Legislação Brasileira. Decreto n ${ }^{\circ}$ 73.684, de 19 de fevereiro de 1974. Available online: https://www.icmbio. gov.br/portal/images/stories/imgs-unidades-coservacao/flona_tapajos.pdf (accessed on 20 July 2020).

23. ICMBIO (Instituto Chico Mendes De Proteção Da Biodiversidade). Ministério Do Meio Ambiente. Unidades de Conservação-Amazônia: Flona do Tapajós, 2020. Available online: https://www.icmbio.gov.br/portal/unidadesdeconservacao/biomas-brasileiros/amazonia/unidadesde-conservacao-amazonia/1963-flona-do-tapajos (accessed on 20 July 2020).

24. Legislação Brasileira. Decreto $n^{\circ}$ 98.704, de 27 de dezembro de 1989. Available online: http://www.planalto. gov.br/ccivil_03/decreto/1980-1989/D98704.htm (accessed on 20 July 2020).

25. Legislação Brasileira. Decreto S/N de 8 de novembro de 2004. Available online: http://www.planalto.gov.br/ ccivil_03/_Ato2004-2006/2004/Dnn/Dnn10350.htm (accessed on 20 July 2020).

26. Legislação Brasileira. Decreto $n^{\circ}$ 2.483, de 2 de fevereiro de 1998. Available online: http://www.planalto.gov. br/ccivil_03/decreto/D2483.htm (accessed on 20 July 2020).

27. Gil, C. Como Elaborar Projetos de Pesquisa, 4th ed.; Atlas: São Paulo, Brazil, 2009.

28. Vergara, S. Métodos de Pesquisa em Administração; Atlas: São Paulo, Brazil, 2005.

29. Cervo, A.; Bervian, P.; Silva, R. Metodologia Científica, 6th ed.; Pearson Prentice Hall: Upper Saddle River, NJ, USA, 2007.

30. Lakatos, M.; Marconi, A. Fundamentos de Metodologia Científica, 5th ed.; Atlas: São Paulo, Brazil, 2003.

31. Legislação Brasileira. Norma Regulamentadora 31-NR 31, Segurança e saúde no trabalho na agricultura, pecuária silvicultura, exploração florestal e aquicultura. 2013. Available online: http://www.guiatrabalhista. com.br/legislacao/nr/nr31.htm. (accessed on 4 August 2020).

32. Lima, C. Manejo Florestal Comunitário na Amazônia Brasileira: Uma abordagem sobre manejo adaptativo e governança local dos recursos florestais em Reserva Extrativista. Universidade Federal do Pará: Belém, Brasil, 2018. Available online: http://repositorio.ufpa.br/jspui/handle/2011/10424 (accessed on 20 July 2020).

33. Johns, J.; Barreto, P.; Uhl, C. Logging damage during planned and unplanned logging operations in the eastern Amazon. For. Ecol. Manag. 1996, 89, 59-77. [CrossRef]

34. Uhl, C.; Barreto, P.; Veríssimo, A.; Vidal, E.; Amaral, P.; Barros, A.; Souza, C., Jr.; Johns, J.; Gerwing, J. Natural resource management in the Brazilian Amazon. Bioscience 1997, 47, 160-168. [CrossRef] 
35. Uhl, C.; Vieira, C. Ecological impacts of selective logging in the Brazilian Amazon: A case study from the Paragominas region of the state of Pará. Biotropica 1989, 21, 98-106. [CrossRef]

36. Pearce, D.; Putz, F.; Vanclay, J. Sustainable forestry in the tropics: Panacea or folly? For. Ecol. Manag. 2003, 172, 229-247. [CrossRef]

37. Leão, R. Avaliação e Otimização do Traçamento da Madeira Tropical: Estudo de Caso no Estado de Amazonas, Brasil. 2012. Available online: https://acervodigital.ufpr.br/handle/1884/27806 (accessed on 20 July 2020).

38. Buchmann, M. Exploração Florestal e Seus Impactos em Áreas de Primeiro e Segundo Ciclo de Corte do Manejo Florestal na Amazônia Oriental, Brasil. Master's Thesis, Universidade de Brasília, Brasília, Brazil, 2016. [CrossRef]

39. Braz, M.; Mattos, P.; Figueiredo, O. Agricultura de precisão: Resultados de um novo olhar-Manejo de precisão em florestas naturais. Embrapa Florestas 2014, 488-491. Available online: http://ainfo.cnptia.embrapa. br/digital/bitstream/item/113993/1/Agricultura-de-precisao-2014.pdf (accessed on 20 July 2020).

40. Nascimento, K.; Emmert, F.; Higuchi, N. Frequência cardíaca para estimativas da carga física de trabalho na exploração florestal. Biofix 2018, 3, 210-215. [CrossRef]

41. Ackerknecht, C. Occupational accidents footprint: New concept linked to chain of custody in sustainable forest management. Cienc. Trab. 2014, 16, 131-136. [CrossRef]

42. Basso, V.; Jacovine, L.; Alves, L.; Vieira, L. Influência da certificação florestal no cumprimento da legislação ambiental e trabalhista na região amazônica. Acta Amaz. 2011, 41, 69-76. [CrossRef]

43. MacDicken, K.; Sola, P.; Hall, J.; Sabogal, C.; Tadoum, M.; Wasseige, C. Global progress toward sustainable forest management. For. Ecol. Manag. 2015, 352, 47-56. [CrossRef]

44. Fernandes, A.; Guimarães, P.; Braz, E.; Hoelflich, V.; Arce, J. Alternativas de planejamento para a exploração florestal. Floresta 2013, 43, 339-350. [CrossRef]

45. Robson, L.; Clark, J.; Cullen, K.; Bielecky, A.; Severin, C.; Bigelow, P.; Irvin, E.; Culyer, A.; Mahood, Q. The effectiveness of occupational health and safety management system interventions: A systematic review. Saf. Sci. 2007, 45, 329-353. [CrossRef]

46. Veiga, J.; Trevisani, D.; Makishi, F.; Abreu, M.; Silva, M.; Zacareli, M. Health and safety standards in labor and extractivism: The case of rural communities in Brazilian Amazon. Saúde E Soc. 2017, 26, 774-785. [CrossRef]

47. Yovi, E.; Nurrochmat, D. An occupational ergonomics in the Indonesian state mandatory sustainable forest management instrument: A review. For. Policy Econ. 2018, 91, 27-35. [CrossRef] 